\title{
The approaches to prevention and therapy of cardiovascular disorders in children with chronic bronchopulmonary pathology
}

\author{
G. 0. Lezhenko, 0. Ye. Pashkova
}

Zaporizhzhia State Medical University, Ukraine

The purpose of this study was to develop and evaluate the algorithm for cardiovascular disorders prevention and therapy effectiveness in children with chronic bronchopulmonary pathology.

Materials and methods. There was catamnestic examination of 57 patients with chronic bronchopulmonary pathology (29 children with severe, controlled or partially controlled persistent bronchial asthma and 28 children with cystic fibrosis and pancreatic insufficiency) who were analyzed the dynamics of left ventricular myocardial remodeling, depending on the administrated treatment. Catamnesis duration was 1 year. The average age of children in the observation group was $9.2 \pm 0.6$ years. The ultrasound examination of the heart was performed using the Medison SonoAce 8000 ultrasound machine (USA) according to the standard procedure. The mathematical analysis and statistical processing of data were performed on a PC using the licensed software package of Statistic for Windows 10.RU using variation, correlation, regression and nonparametric methods of statistical analysis. Variables were expressed as $\mathrm{M} \pm \mathrm{m}$ and $\mathrm{P}$ value $<0.05$ was considered to indicate statistical significance.

Results. It has been established that there is a structural and functional left ventricular myocardium rearrangement on the background of left ventricular diastolic dysfunction development, sympathetic branch of the autonomic nervous system functional impairment, myocardium electrical instability and endothelium-depended vasodilation disturbance in children with chronic bronchopulmonary diseases. The algorithm has been worked out for choosing tactics of cardiovascular disorders therapy based on the study results, which is a complex of non-medicamentous and medicamentous methods with drug modulators of "L-arginine - nitric oxide" system -ACE and L-arginine inhibitors inclusion in the therapy. The effectiveness of proposed algorithm was estimated in 27 children with chronic bronchopulmonary diseases. The other 30 patients, who were treated with traditional therapy, made up a comparison group. It has been found that proposed therapeutic method application in the complex treatment of children with chronic bronchopulmonary pathology contributed to left ventricular myocardium morphofunctional state improvement by slowing processes of left ventricular remodeling and increasing the number of patients who had normal left ventricular myocardium geometry. There was a progression of the left ventricle morphofunctional state changes in the comparison group, which was manifested by an increase in the left ventricular myocardium mass and structural-geometric myocardial restructuring by concentric type of cardiac remodeling.

Conclusions. The use of proposed algorithm can prevent cardiovascular disorders progression and provide more effective rehabilitation of children with chronic bronchopulmonary diseases.

\section{Підходи до профікактики та терапії серцево-судинних порушень у дітей із хронічною патологією бронхолегеневої системи}

\section{Г. О. Аеженко, О. Є. Пашкова}

Мета роботи - розробити та оцінити ефективність алгоритму профрілактики та терапії серцево-судинних порушень у дітей із хронічною патологією бронхолегеневої системи.

Матеріали та методи. Здійснили катамнестичне спостереження за 57 хворими на хронічну бронхолегеневу патологію (29 дітей, які хворі на важку контрольовану або частково контрольовану персистуючу бронхіальну астму, та 28 дітей, які хворі на муковісцидоз із панкреатичною недостатністю), у яких проаналізували динаміку ремоделювання міокарда лівого шлуночка залежно від схеми терапії. Тривалість катамнезу - 1 рік. Середній вік дітей у групі катамнестичного спостереження становив 9,2 \pm 0,6 року. Ультразвукове дослідження серця виконали з використанням еходоплерокардіографра «Medisson 8000» із фазованим датчиком 2-5 ф АС (США) за стандартною методикою з визначенням геометрії міокарда лівого шлуночка. Математичний аналіз і статистичне опрацювання даних виконали на ПЕВМ із використанням ліцензійного пакета програм Statistica for Windows 10.RU із застосуванням варіаційного, кореляційного, регресійного та непараметричних методів статистичного аналізу. Для всіх видів аналізу статистично значущими вважали відмінності при p < 0,05.

Результати. Встановили, що в дітей із хронічними бронхолегеневими захворюваннями відбувається структурно-функціональна перебудова міокарда лівого шлуночка на тлі розвитку діастолічної дисфункції лівого шлуночка, напруження функціонування симпатичного відділу вегетативної нервової системи, електричної нестабільності міокарда та порушення вазодилатуючої функції ендотелію. За результатами дослідження сформували алгоритм вибору тактики терапії кардіоваскулярних порушень, який являє собою комплекс немедикаментозних і медикаментозних заходів із включенням у терапію препаратів-модуляторів системи «L-аргінін - оксид азоту» - інгібіторів AПФ i L-аргініну. Ефекттивність запропонованого алгоритму оцінили у 27 дітей із хронічними захворюваннями бронхолегеневої системи. Інші 30 хворих, які отримували традиційну терапію, ввійшли у групу порівняння. Встановили, що застосування запропонованого терапевтичного алгоритму в комплексі лікування дітей із хронічною бронхолегеневою патологією сприяло поліпшенню морфофункціонального стану міокарда лівого шлуночка внаслідок уповільнення процесів ремоделювання міокарда лівого шлуночка та збільшення кількості пацієнтів, у яких визначили нормальну геометрію міокарда лівого шлуночка. У групі порівняння відбувалося прогресування змін морфофункціонального стану лівого шлуночка серця, що проявлялося збільшенням маси міокарда лівого шлуночка та структурно-геометричною перебудовою міокарда за типом концентричного ремоделювання.

Висновки. Використання запропонованого алгоритму в дітей із хронічними бронхолегеневими захворюваннями дає змогу запобігти прогресуванню кардіоваскулярних розладів і забезпечити ефективнішу реабілітацію дітей із цією патологією.
Key words: pulmonary disease, cystic fibrosis, asthma, child, ACE inhibitors, arginine, cardiovascular system.

\section{Zaporozhye} medical journal

2018; 20 (3), 359-365 Dol:

10.14739/2310-1210. 2018.3.130512

E-mail:

Genalezh@gmail.com, elenapashkova0901@ gmail.com
Киючові слова: мегеневі захворювання, МуКОВісциАОЗ, астма, Аіти, інгібітори АПФ, аргінін, серцево-судинна система.

Запорізький медичний журнал. - 2018. T. 20, № 3(108). C. 359-365 
Ключевые слова: мегочные заболевания, МУКОВиСциАОЗ, астма, Аети, ингибиторы АПФ, аргинин, сердечнососудистая система.

Запорожский медицинский журнал. - 2018. T. 20, № 3(108), C. $359-365$

\section{Подходы к профилактике и терапии сердечно-сосудистых нарушений у детей с хронической патологией бронхолегочной системы}

\section{Г. А. Леженко, Е. Е. Пашкова}

Цель работы - разработать и оценить эффективность алгоритма профилактики и терапии сердечно-сосудистых нарушений у детей с хронической патологией бронхолегочной системы.

Материалы и методы. Проведено катамнестическое наблюдение за 57 больными с хронической бронхолегочной патологией (29 детей, больных тяжелой контролируемой или частично контролируемой персистирующей бронхиальной астмой, и 28 детей, больных муковисцидозом с панкреатической недостаточностью), у которых проанализировали динамику ремоделирования миокарда левого желудочка в зависимости от схемы терапии. Длительность катамнеза - 1 год. Средний возраст детей в группе катамнестического наблюдения составил 9,2 \pm 0,6 года. Ультразвуковое исследование сердца проводили с использованием эходопплерокардиографра «Medisson 8000» с фазированным датчиком 2-5 ф АС (США) по стандартной методике с определением геометрии миокарда левого желудочка. Математический анализ и статистическая обработка данных проведены на ПЭВМ с использованием лицензионного пакета программ Statistic for Windows 10.RU c применением вариационного, корреляционного, регрессионного и непараметрических методов статистического анализа. Для всех видов анализа статистически значимыми считали различия при $p<0,05$.

Результаты. Установлено, что у детей с хроническими бронхолегочными заболеваниями происходит структурно-функциональная перестройка миокарда левого желудочка на фоне развития диастолической диссуункции левого желудочка, напряжения функционирования симпатического отдела вегетативной нервной системы, электрической нестабильности миокарда и нарушения вазодилатирующей функции эндотелия. По результатам исследования сформирован алгоритм выбора тактики терапии кардиоваскулярных нарушений, который представляет собой комплекс немедикаментозных и медикаментозных мероприятий с включением в терапию препаратов-модуляторов системы «L-аргинин - оксид азота» - ингибиторов AПФ и L-аргинина. Эффрективность предложенного алгоритма оценили у 27 детей с хроническими заболеваниями бронхолегочной системы. Остальные 30 больных, которые получали традиционную терапию, составили группу сравнения. Установлено, что применение предложенного терапевтического метода в комплексе лечения детей с хронической бронхолегочной патологией способствовал улучшению морфофункционального состояния миокарда левого желудочка за счет замедления процессов ремоделирования миокарда левого желудочка и увеличения количества пациентов, у которых определена нормальная геометрия миокарда левого желудочка. В группе сравнения происходило прогрессирование изменений морфофуннционального состояния левого желудочка сердца, что проявлялось увеличением массы миокарда левого желудочка и структурно-геометрической перестройкой миокарда по типу концентрического ремоделирования.

Выводы. Использование предложенного алгоритма у детей с хроническими бронхолегочными заболеваниями позволяет предупредить прогрессирование кардиоваскулярных расстройств и обеспечить более эффрективную реабилитацию детей с данной патологией.

Cardiovascular system changes that occur in patients with chronic respiratory diseases lead to early violations of pulmonary-cardiac relations, which result in hypoxic pulmonary vasoconstriction, pulmonary hypertension and chronic heart failure development $[1,2]$. The mechanisms of cardiovascular disorders are associated with the pathogenesis of chronic inflammation, metabolic disturbances of homeostasis, drug-induced cardiotoxicity ( $\beta 2$-agonists, glucocorticoids), chronic hypoxia in chronic bronchopulmonary pathology [3-6]. It is known that hypoxia is one of the main causes of free radical and peroxide oxidation processes activation and oxidative stress development. First of all, it is connecting link in endothelial dysfunction induction and leads to endotheliocytes damage and nitric oxide system dysfunction [7].

The search for reliable markers of cardiohemodynamic disorders at a stage when the cardiovascular changes seriousness is still not high enough allows, in case of timely preventive correction, to prevent the occurrence of severe, life-threatening complications of disease in the future. There are no recommendations on the rational choice of medications for cardiovascular disorders correction in children with chronic bronchopulmonary diseases. In most works the medicamentous correction is aimed at pulmonary hypertension treatment only, that is devoted to cardiovascular complications therapy in children with chronic bronchopulmonary pathology $[8,9]$. There is no doubt, it is justified to prescribe drugs that could not only reduce pulmonary hypertension, but also have an antioxidant effect, reduce endothelial dysfunction manifestations and improve the cardiovascular system morphofunctional state in the treatment of cardiovascular disorders in children with chronic bronchopulmonary pathology.

\section{The purpose of this study}

To develop and evaluate the algorithm for cardiovascular disorders prevention and therapy effectiveness in children with chronic bronchopulmonary pathology.

\section{Materials and methods}

There was catamnestic examination of 57 patients with chronic bronchopulmonary pathology, including 29 patients (10 girls and 19 boys) with severe, controlled or partially controlled persistent bronchial asthma and 28 children ( 16 girls and 12 boys) with cystic fibrosis and pancreatic insufficiency. All children had blood pressure values that were normal for their age, height and sex. The catamnesis duration was 1 year. The average age of children in the observation groups was $9.2 \pm 0.6$ years.

The ultrasound examination of the heart was performed using the Medison SonoAce 8000 ultrasound machine (USA) according to the standard procedure. Morphometric indicators were normalized to the surface area of the body. The left ventricular mass (LVM) was determined in grams ( $\mathrm{g}$ ) 
according to R. B. Devereux et al. formula [10,11]:

$0.8 \times\left[1.04 \times(\text { IST }+ \text { TLVPW + LVEDD })^{3}-\right.$ LVEDD $\left.^{3}\right]+0.6$

IST: the intraventricular septal thickness;

TLVPW: the thickness of the left ventricular posterior wall;

LVEDD: the left ventricular end-diastolic dimension.

Left ventricular mass index (LVMI) was calculated as a ratio of LVM (left ventricular mass) to the height in meters ${ }^{2,7}$ and the remodeling parameter was the left ventricle relative wall thickness to study the processes of left ventricular remodeling [12]. Left ventricular geometry is classified as normal, concentric remodeling, concentric hypertrophy and eccentric hypertrophy [13]

The measurement of nitric oxide metabolites concentration in blood serum was performed by spectrophotometric method with preliminary serum deproteinization and $\mathrm{NO}_{3}$ to $\mathrm{NO}_{2}$ reduction [14].

The mathematical analysis and statistical processing of data were performed on a PC using the licensed software package of Statistic for Windows 10.RU. The parametric variables were compared using the Student's $t$ test for normally distributed data and the Mann Whitney test for non-normally distributed data. Bivariate associations of the variables were assessed using Pearson's correlation coefficients. Variables were expressed as $\mathrm{M} \pm \mathrm{m}$ and $\mathrm{P}$ value $<0.05$ was considered to indicate statistical significance.

\section{Results and discussion}

We have found in our previous studies that left ventricular remodeling occurred in $49 \%$ of patients with bronchial asthma and $58 \%$ of children with cystic fibrosis [15]. Change in the left ventricle geometry occurred against the background of left ventricular diastolic dysfunction development, the sympathetic branch of autonomic nervous system functional overload and electrical myocardial instability $[16,17]$. There was a violation of endothelium-depended vasodilatation, which showed a decrease in the nitric oxide blood serum content by 1,4 times in the group of patients with bronchial asthma and by 6,9 times in patients with cystic fibrosis in comparison with the control group $(7.39 \pm 0.29 \mu \mathrm{mol} / \mathrm{l}$ and $5.79 \pm 0.32$ $\mu \mathrm{mol} / \mathrm{l}$ against $8.88 \pm 0.53 \mu \mathrm{mol} / \mathrm{l}$, respectively, $\mathrm{P}<0.05$ ) [18]. The nitric oxide synthesis was inhibited due to a decrease in the endothelial shear stress, which acts as the main stimulator of nitric oxide activity in patients with chronic bronchopulmonary diseases $[19,20]$. This was confirmed by the obtained direct correlation dependence $(r=+0.42, P<0.05)$ between the index of endothelial shear stress and the level of nitric oxide metabolites. The presence of vascular tone modifying mediators imbalance in children with bronchial asthma and cystic fibrosis led to excessive vasoconstriction development, which manifested as signs of pulmonary hypertension [21].This position was confirmed by the inverse correlation between the level of pulmonary artery pressure and the content of nitric oxide metabolites in blood of children with chronic bronchopulmonary diseases $(r=-0.35, P<0.05$ in the group of patients with bronchial asthma and $r=-0.55, P<0.05-$ in the group of patients with cystic fibrosis) [21].
Table 1. The variants of left ventricular geometry depending on the number of risk factors for cardiovascular disorders development in children with chronic bronchopulmonary diseases

\begin{tabular}{l|l|l|l|}
\hline \multirow{2}{*}{$\begin{array}{l}\text { The variant of left ventricular } \\
\text { geometry }\end{array}$} & \multicolumn{3}{|l}{ The number of risk factors } \\
\cline { 2 - 4 } & $\begin{array}{l}\text { no risk, } \\
\mathbf{n}=\mathbf{6}\end{array}$ & $\begin{array}{l}\mathbf{1 - 2}, \\
\mathbf{n = 2 7}\end{array}$ & $\begin{array}{l}\mathbf{3} \text { and more, } \\
\mathbf{n}=24\end{array}$ \\
\hline Normal & $5(83.3 \%)$ & $12^{1}(44.4 \%)$ & $5^{2,3}(20.8 \%)$ \\
\hline Left ventricle remodeling, including: & $1(16.7 \%)$ & $15^{1}(55.6 \%)$ & $19^{2,3}(79.2 \%)$ \\
\hline Concentric remodeling & 0 & $2(7.4 \%)$ & $4(16.7 \%)$ \\
\hline Concentric hypertrophy & 0 & $6(22.2 \%)$ & $10(37.5 \%)$ \\
\hline Eccentric hypertrophy & $1(16.7 \%)$ & $7(25.9 \%)$ & $5(20.8 \%)$ \\
\hline
\end{tabular}

${ }^{1}: p \varphi<0.05$ - in comparison with the group of children without risk factors;

${ }^{2}: \mathrm{p} \varphi<0.01$ - in comparison with the group of children without risk factors;

3: $p \varphi<0.05-$ in comparison with the group of children who had 1-2 risk factors

Taking into account the obtained study results, risk factors for the morphofunctional restructuring of left ventricular myocardium in children with chronic bronchopulmonary diseases were determined. It was found that the main risk factors for cardiovascular disorders occurrence were the presence of chronic infection, the child age 3-6 years, the disease duration from 3 to 5 years, the circadian index less than 1,2 cu in children with bronchial asthma. The most informative factors were: the child age of 3-6 years old, the respiratory tract colonization by Pseudomonas aeruginosae, severe clinical course of the disease, the presence of chronic infection in the group of children with cystic fibrosis.

In the following we conducted a determination of the left ventricular geometry type depending on the risk factors number for the cardiovascular disorders occurrence in children with chronic bronchopulmonary diseases. The 6 $(10.5 \%)$ patients had no risk factors for cardiovascular disorders, 1-2 risk factors were identified in 27 (47.4\%) children and $24(42.1 \%)$ had 3 and more risk factors for cardiovascular disorders development among observed children.

According to the results of echo-Doppler cardiographic study, the majority of patients, who did not have risk factors for cardiovascular disorders, were diagnosed with a normal version of the left ventricular myocardium in the first study (Table 1).

Among children, who had up to 2 risk factors at the beginning of the observation, the majority of patients $(15-55.6 \%)$ had signs of left ventricular remodeling $(p \varphi<0.05)$. In the group of patients, who had 3 or more risk factors for cardiovascular disorders development, only $5(20.8 \%)$ patients had normal left ventricular geometry. In the other $19(79.2 \%)$ children the signs of left ventricle remodeling were determined among the variants of which concentric hypertrophy prevailed $(p \varphi<0.01)$.

Thus, the risk of cardiovascular complications in the group of patients with chronic diseases increased with a rise in the number of risk factors.

We have formed an algorithm for choosing tactics of cardiovascular disorders therapy in children with chronic bronchopulmonary diseases based on the data obtained (Fig. 1).

At the first stage, cardiovascular risk factors are taken into account and they are come in modified (chronic infection, frequency of exacerbations, airway contamination with Pseudomonas aeruginosae) and unmodified (the age of the child, duration of the disease and severity of the disease course). 


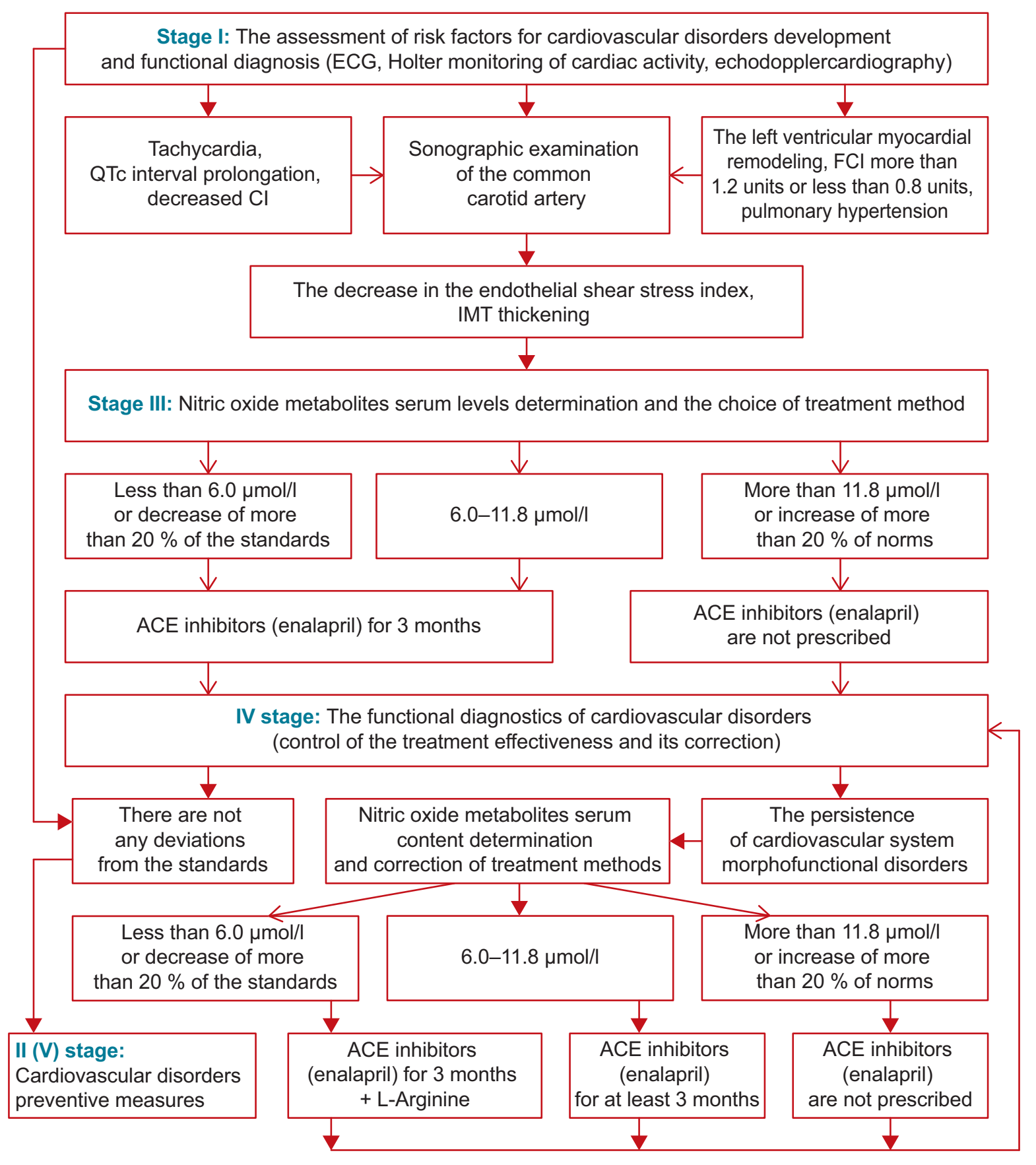

Fig. 1. The algorithm for doctor's action aimed at unifying and increasing the medical care effectiveness for children with chronic bronchopulmonary diseases.

If cardiovascular disorders development was highly probable Dopplerographic examination of the heart was performed with the left ventricular mass index (LVMI), the left ventricular relative wall thickness, the functional compliance index (FCl) definition and sonographic examination of the common carotid artery with the endothelial shear stress index and the intima-media thickness (IMT) determination [19].

At the second stage preventive measures for cardiovascular disorders development are conducted in the absence of cardiovascular disorders. Prevention of cardiovascular disorders is a complex of medicamentous and non-medicamentous measures and should already be conducted at the initial stages of the disease development in children with chronic bronchopulmonary pathology.

The main links in the prevention of cardiovascular disorders:

1. The main disease basic therapy (according to treatment protocols).

2. Therapeutic effect on modified (managed) risk factors for cardiovascular disorders:

a) the sanation of chronic infection; 
b) the specific allergic vaccination of patients achieving bronchial asthma control;

c) the elimination of Ps. Aureginosa in patients with cystic fibrosis.

3. Activities aimed at improving mucociliary transport (exercise therapy, respiratory gymnastics, physiotherapy, therapeutic massage).

4. Dietotherapy. It is recommended to include arginine enriched foods (meat and dairy products, fish and seafood, cereals, legumes) in the food ration of patients with bronchial asthma and cystic fibrosis in the absence of food allergies.

At the third stage, the level of nitric oxide metabolites is examined in the presence of cardiovascular disorders. A decision is made to select a method of cardiovascular disorders correction with drug modulators of "L-arginine - nitric oxide" system - ACE and L-arginine inhibitors inclusion in the therapy depending on the results obtained [22].

The main factor in choice of these drugs using for cardiovascular disorders treatment in the group of patients with chronic bronchopulmonary diseases was the fact that the preparations of this group cause a decrease in vascular tone, mainly arterioles, resulting a decrease in the overall peripheral vascular tone [22]. Also the ACE inhibitors dilate the venous vessels, which return blood to the heart (preload) and pressure to the small blood circulation. The use of ACE inhibitors can reduce post-loading of the left ventricle, peripheral vascular resistance, systolic and diastolic volumes of the left ventricle, increase cardiac output, slow the left ventricular dysfunction progression. Another effect of drugs in this group is the prevention of bradykinin degradation, which leads to smooth muscle relaxation and nitric oxide release [23]. Also, the use of these drugs this group leads to decrease in the sympathetic nervous system effects on vascular tone, resists the left ventricular dilation progression (its remodeling), and causes the reverse development of myocardial hypertrophy [22].

The indications for drugs from the group of ACE inhibitors (enalapril) administration:

The mandatory characteristics:

1. Reducing of nitric oxide metabolites level lower than $20 \%$ of the standards.

2. The presence of left ventricle myocardial hypertrophy.

Main characteristics:

1. Pulmonary hypertension.

2. $\mathrm{FCl}<0.8 \mathrm{cu}$.

3. Tachycardia, decrease in circadian index.

4. Decrease in endothelium shear stress index, IMT thickening.

The enalapril is administrated when obligatory characteristics are combined with one of the main characteristics or if there are 2 or more main characteristics.

The fourth stage: monitoring the therapy effectiveness and treatment correction. The decision is made to apply the standard treatment of children with chronic bronchopulmonary pathology, lengthening the drugs from ACE inhibitors group intake or concerning the additional inclusion into the therapy protocol of drugs from the nitric oxide donators group - L-arginine, which is the main substrate for nitric oxide synthesis in the human body depending on functional methods of investigation results and nitric oxide metabolites blood serum levels determination [24].

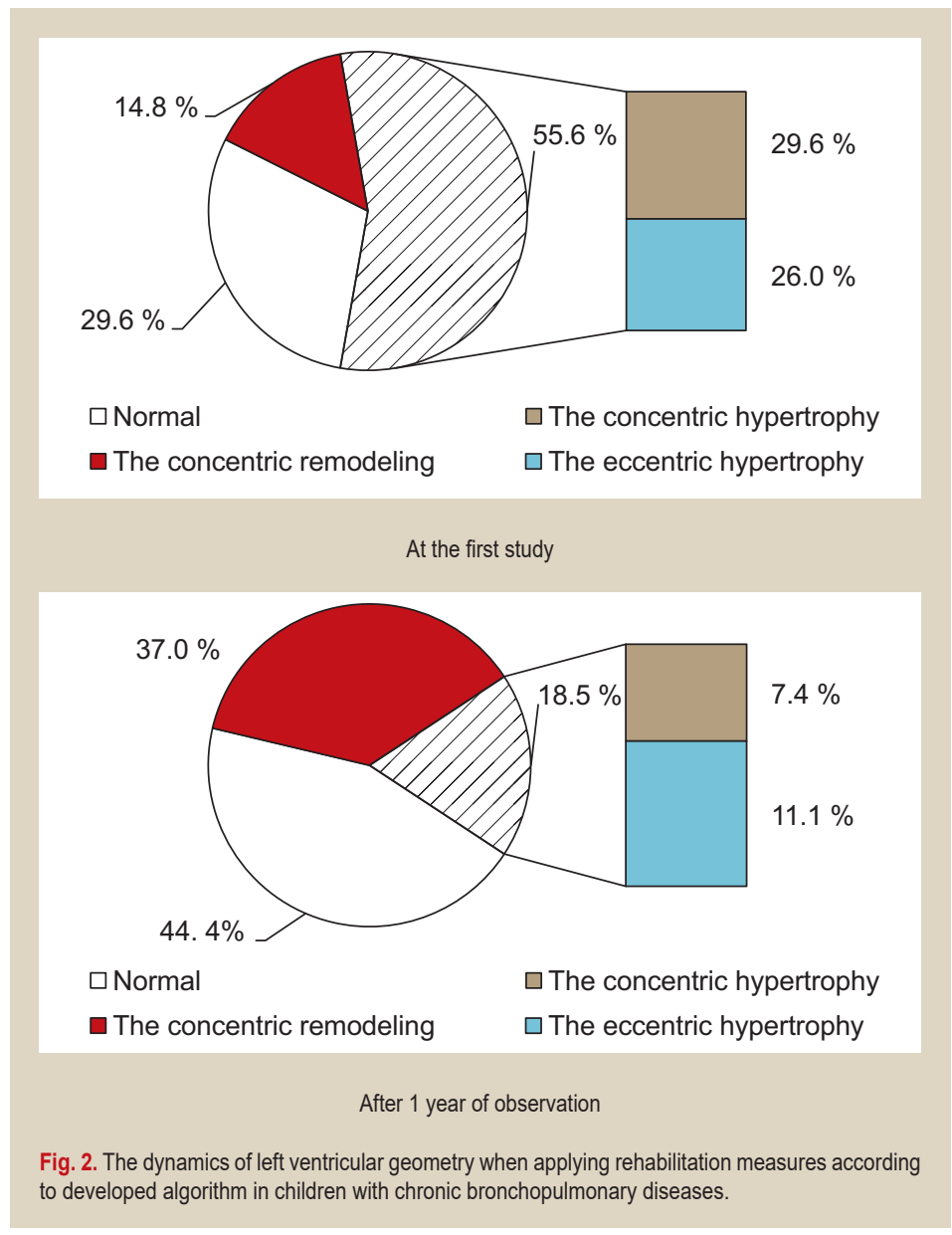

Fifth stage: the measures of cardiovascular disorders secondary prevention (see the second stage).

Cardiovascular disorders correction of can be stopped at any stage if the obtained data as a result of control treatment effectiveness indicate the absence of cardiovascular disorders and endothelial dysfunction functional signs.

The effectiveness of proposed algorithm for cardiovascular disorders therapy was evaluated in the course of 57 patients with chronic bronchopulmonary pathology catamnestic observation, who were analyzed based on dynamics of left ventricular remodeling. The children were divided into 2 groups depending on used therapy. The main group included 27 children, during the period of observation they received periodic courses of therapy, according to our algorithm. The comparison group consisted of 30 patients and for them traditional therapy was used.

The positive effect was observed when used rehabilitation measures in the main group in $10(37 \%)$ patients. If in the first study left ventricular hypertrophy was determined in $15(55.6 \%)$ patients, then in the year of catamnestic observation, the number of children with concentric and eccentric hypertrophy decreased to $5(18.5 \%)$. At the same time, the number of patients with concentric remodeling increased from $4(14.8 \%)$ in the first study to $10(37.0 \%)$ patients after the observation year $(P<0.05)$ and normal left ventricular geometry - from $8(29.6 \%)$ to 12 (44.4\%) patients, respectively (Fig. 2).

In the comparison group only 1 (3.3\%) patient showed significant positive dynamics of the cardiovascular system 


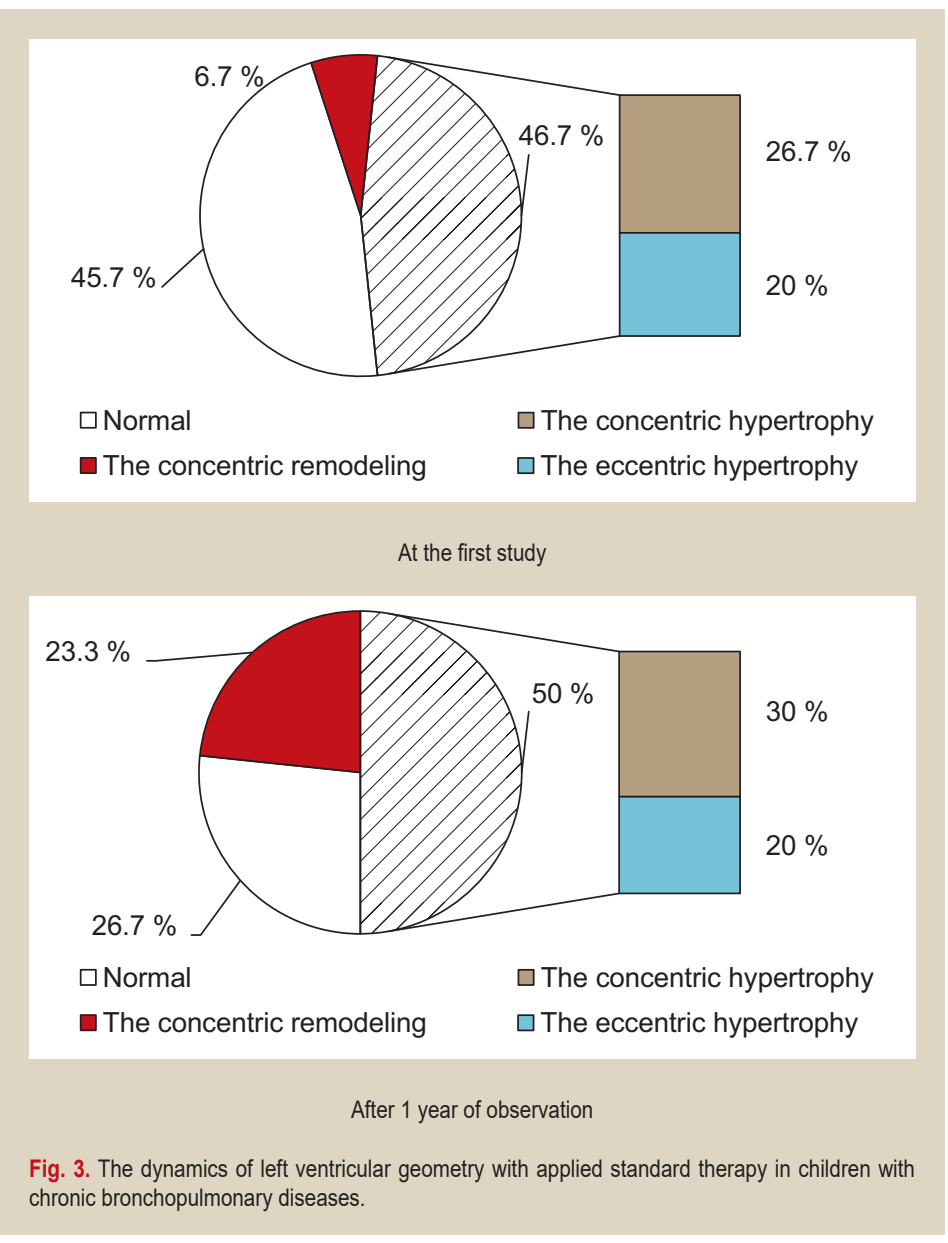

in the first year of study, in whom the concentric left ventricular remodeling was determined in the first study, and in a year of observation - the normal geometry of the left ventricle. The normal version of left ventricular geometry was also determined in both the first and second studies in $7(23.3 \%)$ patients (Fig. 3).

The number of patients with left ventricular hypertrophy did not change much - $15(50.0 \%)$, but there was a tendency to increase in the left ventricular mass index from $36.5 \pm 1.3 \mathrm{~g} / \mathrm{m}^{2,7}$ in the first study up to $39.2 \pm 1.8 \mathrm{~g} / \mathrm{m}^{2,7}$ after a year of catamnestic observation $(P<0.05)$. At the same time, there was a statistically significant increase in the number of patients who had a concentric remodeling of the left ventricle in a year. If at the first study of these patients there were only $2(6.7 \%)$, in a year their number increased to $7(23.8 \%)$ children $(P<0.05)$.

Thus, heart restructuring and changes in intracardiac hemodynamics are complex and associated with many factors, including the development of chronic inflammation, endothelial dysfunction, imbalance of heart rhythm nervous regulation in children with chronic bronchopulmonary diseases. At the same time, myocardial hypertrophy is one of adaptive mechanisms, which allows myocardium to cope with increased stress in conditions of pulmonary hypertension. However, the prolonged pathological effect of various factors on the myocardium limits the important urgent compensatory mechanisms and contributes to the long-term compensatory mechanisms induction, including an increase in the left ventricle volume and mass.
The application of proposed therapeutic method in the complex treatment is pathogenetically substantiated and contributes to the left ventricular myocardium morphofunctional state improvement in children with chronic bronchopulmonary pathology. This was manifested by a slowing down of left ventricular remodeling and an increase in the number of patients who had normal left ventricular geometry.

\section{Conclusions}

1. This scientific work presents clinical-anamnestic rationale for the algorithm of therapeutic measures aimed at cardiovascular system functional state optimizing in children with chronic bronchopulmonary diseases.

2. The proposed algorithm using can prevent cardiovascular disorders progression in children with chronic bronchopulmonary diseases and provide more effective rehabilitation of children with severe pathology.

The prospects. On the basis of the data collected, improvement of cardiovascular disorders therapeutic and prophylactic tactics in children with chronic bronchopulmonary diseases will be continued.

Фінансування: АосліАження виконане в рамках НАР Запорізького Аержавного медичного університету “Активність енАогенних антимікробних пептиАів у Аітей з гострими та рецидивуючими захворюваннями органів Аихання" № Аержреєстрації $0116 \cup 005346$ (2016-2020).

Conflicts of Interest: authors have no conflict of interest to declare. Конфлікт інтересів: віАсутній.

Information about authors:

Lezhenko G. O., MD, PhD, DSc, Professor, Head of the Department of Hospital Pediatry, Zaporizhzhia State Medical University, Ukraine.

Pashkova O. Ye., MD, PhD, DSc, Associate Professor of the Department of Hospital Pediatry, Zaporizhzhia State Medical University, Ukraine.

\section{Відомості про авторів:}

Леженко Г. О., А-р меА. наук, професор, зав. каф. госпітальної пеАіатрії, Запорізький Аержавний медичний університет, Україна.

Пашкова 0. Є., А-р меА. наук, Аоцент каф. госпітальної педіатрії, Запорізький Аержавний медичний університет, Україна.

\section{Сведения об авторах:}

Леженко Г. А., А-р меА. наук, профессор, зав. каф. госпитальной педиатрии, Запорожский госуАарственный меАицинский университет, Украина.

Пашкова Е. Е., А-р меА. наук, Аоцент каф. госпитальной пеАиатрии, Запорожский госуАарственный меАицинский университет, Украина.

Надійшка Ао реАакції / Received: 27.12.2017

Після Аоопрацювання / Revised: 19.01.2018

Прийнято АО Аруку / Accepted: 24.01.2018

\section{References}

[1] Cazzola, M., Calzetta, L., Bettoncelli, G., Novelli, L., Cricelli, C., \& Rogliani, P. (2011). Asthma and comorbid medical illness. Europ. Resp. J., 38(1), 42-49. doi: 10.1183/09031936.00140310.

[2] Roy, R., \& Couriel J. M. (2006). Secondary pulmonary hypertension. Paediatric Respiratory Reviews., 7(1), 36-44. 
[3] Nedel'skaya, S. N., Srebrodol'skaya E. V., \& Bessikalo, T. G. (2010). Izmenenie gemodinamicheskikh pokazatelej u detej s bronkhial'noj astmoj [The change in hemodynamic parameters in children with bronchial asthma]. Zaporozhye medical journal, 12(2), 43-47. [in Russian].

[4] Venkatesan, A., Spalding, C., Speedie, A., Sinha, G., \& Rumbaugh, J. A. (2005). Pseudomonas aeruginosa infective endocarditis presenting as bacterial meningitis. J. Infect., 51(4), 199-202. doi: 10.1016/j. jinf.2005.02.019

[5] Nagra, A., Maddock, H., \& Hussain, A. (2011). The bronchodilator salbutamol is associated with increased myocardial injury in a pre-clinical heart attack model. Heart., 97, e1-e2.

[6] Manara, A., Hantson, Ph., Vanpee, D., \& Thys, F. (2012). Lactic acidosis following intentional overdose by inhalation of salmeterol and fluticasone. Canadian Journal of Emergency Medicine., 14(6), 378-81.

[7] Abaturov, A. E. (2009). Rol' monooksida azota v sisteme nespecificheskoj zaschity respiratornogo trakta [The role of nitrogen monoxide in the system of nonspecific protection of the respiratory tract]. Zdorov'e rebenka, 1, 130-137. [in Russian].

[8] Papi, A., Nicolini, G., Baraldi, E., Boner, A. L., Cutrera, R., Rossi, G. A., \& Fabbri, L. M. (2009). Regular vs prn nebulized treatment in wheeze preschool children. BEclomethasone and Salbutamol Treatment (BEST) for Children Study Group.Allergy., 64(10), 1463-71. doi: 10.1111/j.13989995.2009.02134.x.

[9] Chaumais, M. -C., Macari, E. A., \& Sitbon, O. (2013). Calcium-Channel Blockers in Pulmonary Arterial Hypertension. Pharmacotherapy of Pulmonary Hypertension., 218, 161-175. doi: 10.1007/978-3-64238664-0 7.

[10] National High Blood Pressure Education Program Working Group on High Blood Pressure in Children and Adolescents. (2004). National High Blood Pressure Education Program Working Group on High Blood Pressure in Children and Adolescents The Fourth Report on the Diagnosis, Evaluation, and Treatment of High Blood Pressure in Children and Adolescents. Pediatrics., 114(2), 555-576.

[11] Devereux, R. B., Alonso, D. R., Lutas, E. M., Gottlieb, G. J., Campo, E., Sachs, I., \& Reichek, N. (1986). Echocardiographic assessment of left ventricular hypertrophy: comparison to necropsy findings. Am J Cardiol., 57, 450-458.

[12] De Simone, G., Devereux, R. B., Daniels, S. R., Koren, M. J., Meyer, R. A., \& Laragh, J. H. (1995). Effect of growth on variability of left ventricular mass: assessment of allometric signals in adults and children and their capacity to predict cardiovascular risk. J. Amer. Coll. Cardiology., 25, 1056-1062. doi: 10.1016/0735-1097(94)00540-7.

[13] Daniels, S. R., Kimball, T. R., Morrison, J. A., Khoury, P., \& Meyer, R. A (1995). Indexing left ventricular mass to account for differences in body size in children and adolescents without cardiovascular disease. Am. J. Cardiol., 76, 699-701. doi: https://doi.org/10.1016/S00029149(99)80200-8.

[14] Golikov, P. P. \& Nikolayeva, N. Yu. (2004). Metod opredeleniya nitrita/ nitrata (NOx) v syvorotke krovi [Method of the measurement of nitrite/ nitrate (NOx) in serum]. Biomedicinskaya khimiya, 50(1), 79-85. [in Russian].

[15] Pashkova, O. E. (2011). Osoblyvosti morfofunktsionalnoho stanu miokarda livoho shlunochka u ditei z khronichnoiu bronkholehenevoiu patolohiieiu [The features of the morphofunctional state of the left ventricular myocardium in children with chronic bronchopulmonary pathology]. Current issues in pharmacy and medicine: science and practice, 2, 293-298. [in Ukrainian].

[16] Lezhenko, G. A. \& Pashkova, E. E. (2012). Stan neiroendokrynnoi rehuliatsii sertsevoho rytmu u ditei, khvorykh na bronkhialnu astmu ta retsydyvuiuchyi bronkhit [The state of the neuroendocrine regulation of heart rate in children with bronchial asthma and recurrent bronchitis]. Problemy endokrynnoi patolohii, 4, 79-84. [in Ukrainian].

[17] Pashkova, O. E., \& Lezhenko, G. O. (2012). Obgruntuvannia patohenetychnoi terapii sertsevo-sudynnykh porushen u ditei, khvorykh na mukovistsydoz [The substantiation of pathogenetic therapy of cardiovascular disorders in children suffering from cystic fibrosis]. Vestnik fizioterapii $i$ kurortologii, 3, 64-67. [in Ukrainian].

[18] Lezhenko, G., \& Pashkova, E. (2014). Markery razvitiya serdechno-sosudistykh narushenij u detej s bronkholegochnoj patologiej [The markers of cardiovascular disorders formation in children with bronchopulmonary diseases]. Pediatriya. Vostochnaya Evropa, 1(5), 49-57. [in Russian].

[19] Pashkova, O. E., \& Lezhenko, G. O. (2017). Morfofunktsionalni osoblyvosti miokarda livoho shlunochka ta zahalnykh sonnykh arterii u ditei, khvorykh na mukovistsydoz [The morphofunctional features of the left ventricular myocardium and common carotid arteries in children with cystic fibrosis]. Zdorov'e rebenka, 5, 7-12. [in Ukrainian].

[20] Melnikova, L. V. (2011). Znachenie gemodinamicheskikh faktorov $v$ razvitii remodelirovaniya sosudov myshechno-e'lasticheskogo tipa pri arterial'noj gipertenzii [Importance of hemodynamic factors in vascular remodeling of muscular elastic type in arterial hypertension]. Saratovskij nauchno-medicinskij zhurnal, 7(1), 76-79. [in Russian].

[21] Lezhenko, H. O., \& Pashkova, O. Ye. (2013). Stan funktsii endoteliiu u ditei z khronichnymy ta retsydyvnymy zakhvoriuvanniamy bronkholehenevoi systemy [The state of the endothelial function in children with chronic and recurrent bronchopulmonary diseases of the bronchopulmonary system]. Bukovynskyi medychnyi visnyk, 17, 3(67), 2 48-52. [in Ukrainian]

[22] Nagornaya, N. V., \& Parshin, S. A. (2010). Ingibitory APF. Vozmozhnost' primeneniya v pediatricheskoj praktike [The ACE inhibitors. Possibility of application in pediatric practice]. Zdorov'e rebenka, 3, 113-115. [in Russian].

[23] Agapitov, L. I. (2012). Diagnostika i lechenie legochnogo serdca u dete [The diagnosis and treatment of pulmonary heart in children]. Lechaschij vrach, 8, 47-54. [in Russian].

[24] Böger, R. H. (2007). The pharmacodynamics of L-arginine. The Journal of nutrition, 137(6), 1650S-1655S. doi: 10.1093/jn/137.6.1650S. 